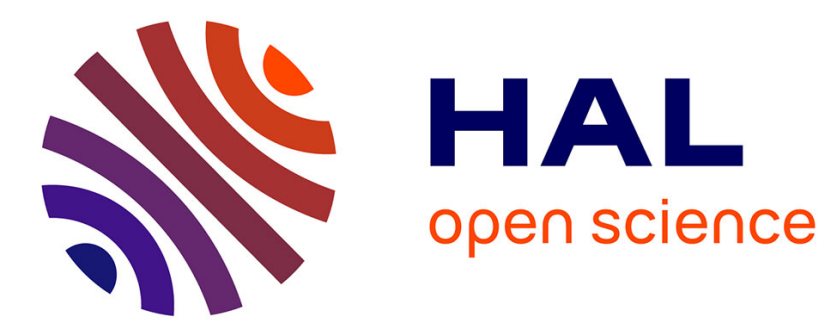

\title{
Photocatalysts in Polymerization Reactions
}

Nicolas Zivic, Mariem Bouzrati-Zerelli, Anthony Kermagoret, Frédéric

Dumur, Jean-Pierre Fouassier, Didier Gigmes, Jacques Lalevée

\section{To cite this version:}

Nicolas Zivic, Mariem Bouzrati-Zerelli, Anthony Kermagoret, Frédéric Dumur, Jean-Pierre Fouassier, et al.. Photocatalysts in Polymerization Reactions. ChemCatChem, 2016, ChemCatChem, 8 (9), pp.1617-1631. 10.1002/cctc.201501389 . hal-01346412

\section{HAL Id: hal-01346412 \\ https://hal.science/hal-01346412}

Submitted on 18 Jul 2016

HAL is a multi-disciplinary open access archive for the deposit and dissemination of scientific research documents, whether they are published or not. The documents may come from teaching and research institutions in France or abroad, or from public or private research centers.
L'archive ouverte pluridisciplinaire HAL, est destinée au dépôt et à la diffusion de documents scientifiques de niveau recherche, publiés ou non, émanant des établissements d'enseignement et de recherche français ou étrangers, des laboratoires publics ou privés. 


\title{
Photocatalysts in Polymerization Reactions
}

Nicolas Zivic, ${ }^{\mathrm{a}}$ Mariem Bouzrati-Zerelli, ${ }^{\mathrm{b}}$ Anthony Kermagoret, ${ }^{\mathrm{a} *}$ Frédéric Dumur, ${ }^{\mathrm{a}}$ JeanPierre Fouassier ${ }^{1, \mathrm{~b}}$ Didier Gigmes, ${ }^{\mathrm{a}}$ and Jacques Lalevée ${ }^{\mathrm{b}_{*}}$

a Aix-Marseille Université, CNRS, Institut de Chimie Radicalaire ICR, UMR 7273, F- 13397 Marseille, France.

${ }^{\mathrm{b}}$ Institut de Science des Matériaux de Mulhouse IS2M, UMR CNRS 7361, UHA, 15, rue Jean Starcky, 68057 Mulhouse Cedex, France.

*corresponding authors: anthony.kermagoret@univ-amu.fr; jacques.lalevee@uha.fr

\begin{abstract}
:
A short review on the role of photocatalysts in photopolymerization reactions is presented. A special emphasis is done on photoredox catalysts leading to i) high performance initiating systems for polymerization upon low light intensity for the use of light emitting diodes (LEDs) and/or visible light or ii) Controlled Radical PhotoPolymerization (CRP2) processes with formation/reactivation of dormant species triggered by light.
\end{abstract}

Keywords: photoredox catalysis, photocatalysts, radical photopolymerization, cationic photopolymerization, controlled radical polymerization.

${ }^{1}$ Formerly, ENSCMu-UHA, 3 rue Alfred Werner 68057 Mulhouse-France. 


\section{Contents:}

1 - Introduction

2 - Specific and basic questions about photoinitiating systems (PISs)

3 - Photocatalysts (PCs) in high performance photoinitiating systems for polymerization reactions

4 - Photocatalysts (PCs) in controlled radical photopolymerization reactions

5 - Outlook

6 - References 


\section{Abbreviations:}

CRP2 Controlled Radical PhotoPolymerization

PI Photoinitiator

LED Light Emitting Diode

PIS Photoinitiating System

PS Photosensitizer

FRPCP Free Radical Promoted Cationic Polymerization

PC

Photocatalyst

FRP

Free Radical Polymerization

$\mathrm{CP}$

Cationic Polymerization

$\mathrm{P}_{\text {Eff }} \quad$ Photoinitiation efficiency

$\mathrm{P}_{\mathrm{Ab}} \quad$ Polymerization ability

$\Phi_{\mathrm{i}} \quad$ Quantum yield

$\mathrm{I}_{\mathrm{abs}}$

Absorbed energy

Rp Polymerization rates

$\mathrm{k}_{\mathrm{p}} \quad$ Propagation rate constant

$\mathrm{k}_{\mathrm{t}} \quad$ Termination rate constant

EY Eosin Y

DH Hydrogen donor

A Electron acceptor

NVK $\quad N$-vinyl carbazole

CRCP Concomitant Radical/Cationic Polymerization

MPC Metal based photocatalyst

OPC Organic photocatalyst

$\mathrm{Ph}_{2} \mathrm{I}^{+} \quad$ Iodonium salt

$\mathrm{AH} \quad$ Amine

ATRP Atom Transfer Radical Polymerization

$\mathrm{MB}^{+} \quad$ Methylene blue

LMB Leuco-methylene blue

DIPEA Diisopropylethylamine

MMA Methyl methacrylate

EDB Ethyldimethylaminobenzoate 
PBN Phenyl-N-tert-butylnitrone

ESR Electron Spin Resonance

NMP Nitroxide Mediated Polymerization

RAFT Reversible-Fragmentation chain Transfer

OMRP Organometallic Radical Mediated Polymerization

ITP Iodine-Transfer Polymerization

TERP Tellurium mediated Radical Polymerization

CRP Controlled Radical Polymerization

ICAR Initiators for Continuous Activator Regeneration

AGET Activators Generated by Electron Transfer

GAMA Generation of Activators by Monomer Addition

PET-RAFT Photoelectron Transfer RAFT

MF ATRP Metal-Free ATRP

$\mathrm{Ph}-\mathrm{PTZ}$ 10-phenylphenothiazine

RCMP Reversible Complexation Mediated living radical Polymerization 


\section{1 - Introduction}

Photopolymerization reactions are already encountered for applications in various industrial sectors e.g. Radiation Curing (coatings, adhesives, inks, paints, graphic arts, composites... $),{ }^{[1]}$ microelectronics, ${ }^{[2]}$ Laser Direct Imaging technology, ${ }^{[3]}$ Computer-To-Plate processing, 3D printing through the stereolithography approach, ${ }^{[4]}$ holographic recording and information storage, ${ }^{[5]}$ manufacture of optical elements, ${ }^{[6]}$ dentistry, ${ }^{[7]}$ medicine (e.g. surgical glue $),{ }^{[8]}$ design of structured materials on the nanoscale size and imaging areas. ${ }^{[9]}$

In addition, the photopolymerization area presents important economic and environmental advantages since this process does not require the use of solvents, is low energy consuming and proceeds at room temperature with very short reaction times. ${ }^{[10]}$

The photopolymerization process is induced by a photoinitiator (PI) or a PhotoInitiating System (PIS) which, under irradiation, generates active species initiating the polymerization according to a radical or a cationic mechanism, and more rarely an anionic one (Scheme 1). ${ }^{[11]}$

A photopolymerization reaction can be initiated through different pathways. For rather classical systems, PI can produce the active radical species via (i) a homolytic bond cleavage for Type I photoinitiators or (ii) through hydrogen abstractions with hydrogen donors (also called a co-initiators) for Type II photoinitiators. The sensitization of the photoinitiator through the use of a photosensitizer (PS) is also possible and can be an interesting process to shift the light absorption properties of the PS/PI system vs. PI alone (Scheme 1). ${ }^{[10 a, 12]}$

Scheme 1. Type II photopolymerization mechanism and potential use of a photosensitizer (PS). 
Type I or Type II photoinitiators generate radical species which widely react on the double bonds of vinyl monomers and initiate the radical polymerization. Cationic polymerizations are usually preceded by photolysis of onium compounds (iodonium, sulfonium, pyridinium, diazonium, pyrylium, etc) and the resulting cationic species or strong acids initiate a ring opening polymerization on epoxides ${ }^{[13]}$ or oxetanes ${ }^{[14]}$ or react on double bonds of vinyl ethers, vinyl carbazole or styrene. ${ }^{[10 a, 15]}$

However the two-component Type II systems are usually characterized by a rather moderate reactivity due to numerous kinetic limitations (bimolecular reaction, back electron transfer, radical recombination and parallel production of inefficient radical able to terminate a growing polymer chain) and therefore cannot replace the Type I system used in UV-light activated polymerization where reaction rate is a primarily consideration. ${ }^{[10 a]}$

To overcome these restrictions, additional components were introduced in the system. Indeed multi-component systems increase the yield of initiating radicals by converting terminating radicals (generally $\mathrm{PIH}^{*}$, Scheme 2) to new initiating species. ${ }^{[10 a, 16]}$ Generally, three-component initiator systems consist of a PI, an electron/hydrogen donor DH and an electron acceptor A (an oxidation agent that is classically an iodonium salt), where the A increases the photopolymerization kinetics, by consuming an inactive $\mathrm{PIH}^{\circ}$ radical to produce another active radical $\mathrm{A}^{*}$, thereby regenerating the original PI and limiting the concurrent production of inefficient radicals (Scheme 2). The initiating radical quantum yield for threecomponent system are increased by a factor two (only $\mathrm{D}^{\bullet}$ initiate the polymerization for $\mathrm{PI} / \mathrm{DH}$ compared to both $\mathrm{D}^{\bullet}$ and $\mathrm{A}^{\bullet}$ for $\left.\mathrm{PI} / \mathrm{DH} / \mathrm{A}\right) .^{[11,16-17]}$

Scheme 2. Example of three-component systems (PI/DH/EA).

An ultimate improvement of three-component initiator systems was achieved when the PIs were regenerated during the process (Scheme 2) and consequently behave as photocatalysts (PC). ${ }^{[10 a, 18]}$ The photocatalyst in PIS can be very worthwhile for the access to very efficient systems since the PC is regenerated in the catalytic cycle and, therefore, a low 
amount is necessary and/or a low light intensity is necessary (i.e. through an increase of the photosensitivity of the system).

Recently, the utilization of photocatalysts (PCs) (both metal-based structures or organic molecules) in photoredox catalysis processes has emerged as an innovative strategy in organic synthesis for the generation of free radicals upon soft irradiation conditions (daylight, LED bulbs ....). ${ }^{[19]}$ Newly introduction of PCs in photo-initiating systems has permitted to open important perspectives in radical and cationic polymerization. ${ }^{[18 b, 20]}$ In particular the use of PCs does not required expensive and specialized photochemical equipments since these systems are efficient with low light intensity and light emitting diodes or other cheap irradiation devices can be used, as well as the sunlight (see below).

In this review, we present the development and the associated chemical mechanisms of the most recent photocatalytic systems applied in photopolymerization reactions, i.e. for i) free radical and/or cationic polymerization ${ }^{[21]}$ and ii) the controlled radical photopolymerization CRP2. ${ }^{[22]}$

\section{2 - Specific and basic questions about photoinitiating systems (PISs)}

To operate, a photocatalyst must have at least one photosensitive function, called a chromophore, to absorb the light (photons) and consequently to convert the light to active species (radical, cations ...) able to initiate a polymerization reaction. Three properties of PCs, i.e. light absorption, redox potentials and long lifetime of excited states, are decisive for the efficiency of the photopolymerization process.

\section{2a) Generalities of the PIs}

Accordingly, the photopolymerization using a given PI system depends of the relationships between the photoinitiation efficiency $\mathrm{P}_{\mathrm{Eff}}$ and the polymerization ability $\mathrm{P}_{\mathrm{Ab}}$. The $\mathrm{P}_{\mathrm{Ab}} \mathrm{S}$ are visualized by the polymerization rates and the final conversions of the monomer whereas $\mathrm{P}_{\mathrm{Eff}} \mathrm{s}$ are reflected by the initiation quantum yield $\Phi_{\mathrm{i}}$. This $\Phi_{\mathrm{i}}$ term corresponds to the number of starting polymer chains per absorbed photon; it is connected to the rate constants of the reactions leading to the initiating species or to competitive detrimental quenchings of the excited states generated after light absorption by the PI. The polymerization rates are dependent on the rate constants of the polymerization, the initiation quantum yield $\Phi_{\mathrm{i}}$ and the amount of absorbed energy $I_{a b s}\left(I_{a b s}=I_{0}\left(1-10^{-\varepsilon c l}\right)\right.$ (where $I_{o}$ stands for the incident light intensity of the source, $\varepsilon$ the molar extinction coefficient of PI, 1 the path length and $\mathrm{c}$ the PI 
concentration). The final conversions usually increase with the polymerization rates. The possibility to have high polymerization rates (and high conversions) are achieved using (i) highly absorbing (high $\varepsilon$ value) and (ii) very reactive (high $\Phi_{\mathrm{i}}$ value) PIs or/and high intensity light sources and high PI concentrations.

\section{2b) Properties of photocatalysts: Absorption}

Photocatalysts are characterized by an absorption spectrum in the UV, visible, or very near-infrared wavelength range corresponding to electronic transitions, in particular HOMO $\rightarrow$ LUMO transitions, after absorption of photons by the various functions of their skeleton.

Firstly, the absorption spectrum of a PC must exhibit the best possible matching with the emission spectrum of the light source and the highest $\varepsilon$ values $\left(\varepsilon_{\max }\right)$. Therefore, the choice of the PC is strongly connected with the light sources required and the application (conventional devices and novel irradiation sources such as LEDs and laser diodes). The design of visible light harvesting PCs is an attracting and key challenge. ${ }^{[23]}$ Nowadays, a key research direction concerns the photopolymerization under softer irradiation conditions (near UV or visible light as well as rather low light intensity). ${ }^{[24]}$ Indeed, near UV or visible light sources are safer, cheaper and penetrate deeply in thick samples. (Quasi)monochromatic sources (e.g. 385, 395, 405, 420, 455, 470, 477, 512, 532, $635 \mathrm{~nm}$ etc ...) using Light Emitting Diodes (LEDs) and laser diodes, polychromatic light using household halogen lamps or fluorescent bulbs can be accessible. These irradiation devices (particularly LEDs) are also environmentally friendly (low energy consumption, no $\mathrm{Hg}$ involved, no ozone released, high lifetimes ....). ${ }^{[24]}$

Numerous methods have been used to reduce HOMO-LUMO gap and consequently to increase the absorption of less energitic photons, in other words to absorb light at higher wavelength. Amongst them, elaboration of organometallic compounds, ${ }^{[25]}$ push-pull molecules $^{[26]}$ (that consist of an electron donating group and an electron withdrawing group coupled through a $\pi$-conjugated spacer) and highly conjugated $\pi$-systems ${ }^{[27]}$ allowed to obtain photocatalysts exhibiting an absorption in a visible range with high molar extinction coefficients. 


\section{2c) Properties of photocatalysts: Reactivity}

Consequences of HOMO-LUMO transitions induced by light absorption, electron donation/acceptation properties of the excited state PCs are dramatically modified which highly affects the redox potentials of the PC. ${ }^{[23 b, 28]}$

For example, the redox potentials of $\mathrm{Ru}(\mathrm{bpy})_{3}{ }^{2+}$ and Eosin Y (EY, Figure 1), estimated at the excited state, illustrate the highly favourable reducing and oxidizing potentials of these photoinitiators (Figure 1). ${ }^{[19 c, 29]}$

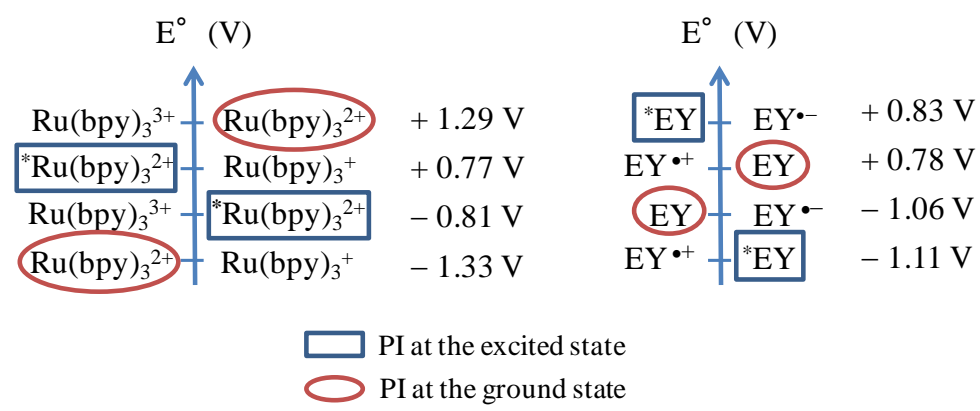

Figure 1. Reducing and oxidizing potentials of Ru(bpy) ${ }_{3}{ }^{2+}$ and Eosin Y (vs Saturated Calomel Electrode). ${ }^{[19 c, 29]}$

Finally, in its excited state, the photocatalyst presents highly reactive redox potentials, with respect to its ground state, allowing to react efficiently with oxidation and reduction agents in catalytic cycles to generate the active initiating species (radical and cations).

But photocatalytic reactions need also intermolecular interactions and so, required a long lifetime excited states (singlet or triplet, Figure 2) ${ }^{[30]}$ of PC* that can be quenched by a donor or an acceptor for an efficient production of initiating species. As illustrated in a Jablonski's diagram ${ }^{[31]}$, the light absorption of the chromophore induced new electronic states (Figure 2). The excited triplet state of Type I PIs presents, in general, a very short lifetime (in the ps domain) which is characteristic of an efficient homolytic bond cleavage; this lifetime is too short to allow a reaction between the $\mathrm{PI}^{*}$ and a acceptor or a donor (Figure 2). Having reasonable excited states, the $\mathrm{PC}^{*}$ can react with an electron/hydrogen donor, e.g. an amine, ${ }^{[10]}$ a silane, ${ }^{[32]}$ a germane, ${ }^{[32-33]}$ or can react with an electron acceptor, e.g. an iodonium salt, ${ }^{[13 a, 34]}$ an alkyl halide ${ }^{[16]}$ or a vinyl ether to initiate a ring opening metathesis polymerization as reported recently. ${ }^{[35]}$ Consequently the design of PC presenting long lifetime exited states is a key parameter for efficient biomolecular PC*/additive reactions and therefore for an effective photocatalytic system. 


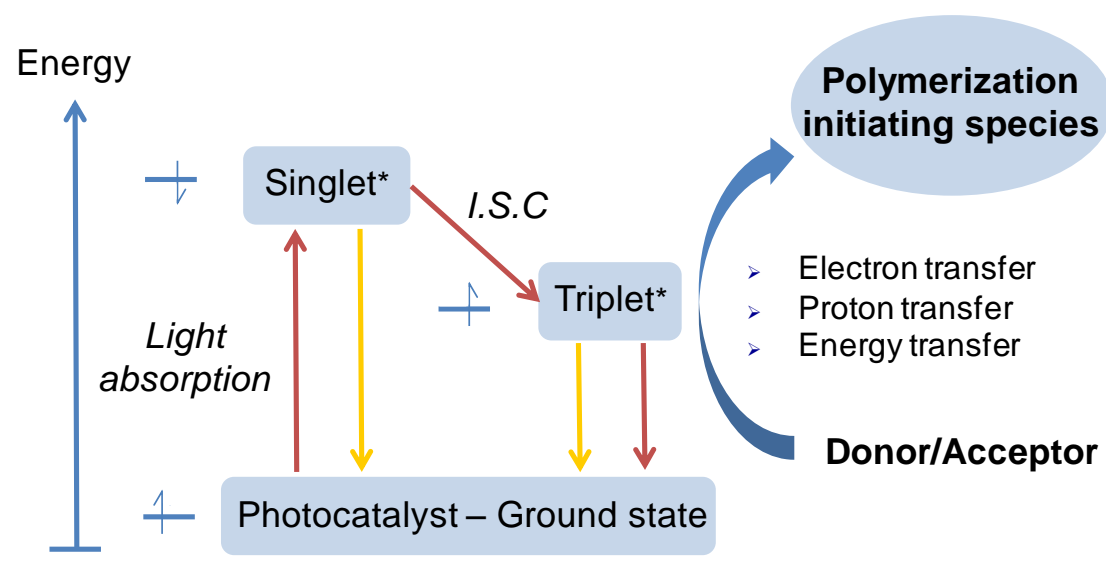

Figure 2. Perrin-Jablonski's diagram; example of a reactivity from a triplet state.

Finally, the efficiency of the photocatalyst depends of its high photoluminescence quantum yield, fine balance between high reactivity at the excited state (ability to induce an electron/hydrogen transfer with a donor/acceptor) and a long lifetime excited state to undergo the intermolecular reactions but also a good reversibility minimizing the by-side reactions.

\section{3- PCs in photopolymerization reactions}

\section{3a) PC based systems}

Photoredox catalysts are now widely used in organic chemistry under very soft irradiation conditions. ${ }^{[19 b, 19 d, 23 a, 36]}$ The mechanisms involved in PC systems basically lie on oxidation and reduction cycles with $\mathrm{PC}^{*} / \mathrm{PC}^{-\mathrm{I}}$ (reductive pathway) or $\mathrm{PC} / \mathrm{PC}^{+\mathrm{I}}$ (oxidative pathway) couples (Scheme 3). ${ }^{[18 b, 20 b]}$

Scheme 3. Reductive and oxidative photoredox catalytic cycles. 
In polymerization, the regeneration of the absorbing compound, while keeping a high reactivity/efficiency, is a major issue. Three factors appear to be very important: i) a long lifetime of the excited state (*PC) to favour the PC*/A or PC*/D quenching reactions, ii) adapted redox potentials also for efficient electron transfer reaction in the catalytic cycles presented in Scheme 3 and iii) a good reversibility in redox process to minimize the degradation of $\mathrm{PC}^{\bullet+}$ and $\mathrm{PC}^{\bullet-}$ for a good regeneration of the catalyst (see above).

The successful results are undoubtedly related to the precise mixtures of several components which act as $\mathrm{PC}^{*}$ reductants or oxidants. Mainly, three systems have been designed for high performance Photoredox catalytic polymerization: i) the PC/amine(AH)/alkyl halide system; ii) the PC/iodonium salt $\left(\mathrm{Ph}_{2} \mathrm{I}^{+}\right) /$silane system and iii) the PC/iodonium salt $\left(\mathrm{Ph}_{2} \mathrm{I}^{+}\right) / N$-vinylcarbazole system.

In the three components system PC/amine/alkyl halide (Scheme 4), the amine reacts as a $\mathrm{PC}^{*}$ reductant to generate the $\mathrm{PC}^{*-}$ species. Indeed aliphatic amines are efficient and wellknown electron sacrificial donors in numerous redox systems. ${ }^{[37]}$ As a side reaction, the resulting radical species $\left(\mathrm{AH}^{\circ+}\right.$ in Scheme 4) can undergo an additional $\mathrm{H}$-abstraction to generate an amino-radical species which widely initiates a polymerization but lead to the degradation of PC. Fortunately in most cases, the $\mathrm{PC}^{*-}$ species reacts with the alkyl halide, usually a phenacyl bromide as $\mathrm{R}-\mathrm{Br}$ or chlorotriazine $\mathrm{R}-\mathrm{Cl},{ }^{[20 \mathrm{~b}]}$ to generate a phenacyl bromide radical anion intermediate $\left(\mathrm{R}^{\left.-\mathrm{Br}^{\circ}\right)}\right.$ ) and the initial $\mathrm{PC}$. The initiating phenacyl radical $\left(\mathrm{R}^{\circ}\right.$, Scheme 4) is produced from the degradation of $(\mathrm{R}-\mathrm{Br})^{\circ-}$ and initiates the free radical polymerization of acrylate and methacrylate monomers. ${ }^{[20 \mathrm{~b}]}$

Scheme 4. Reaction mechanisms for the PC/amine/phenacyl-Br system.

In contrast, the PC/iodonium salt $\left(\mathrm{Ph}_{2} \mathrm{I}^{+}\right)$/silane $\left(\mathrm{R}_{3} \mathrm{SiH}\right)$ (or $N$-vinylcarbazole NVK instead of silane) follows an oxidative pathway (Scheme 5). Acting as an oxidant, $\mathrm{Ph}_{2} \mathrm{I}^{+}$reacts 
with the $\mathrm{PC}^{*}$ species. The unstable radical $\mathrm{Ph}_{2} \mathrm{I}^{*}$ breaks into $\mathrm{PhI}$ and the polymerization initiator $\mathrm{Ph}^{*}$. Then, a silyl radical $\mathrm{R}_{3} \mathrm{Si}^{\bullet}$ and a silylium $\mathrm{R}_{3} \mathrm{Si}^{+}$are formed through subsequent $\mathrm{Ph} / \mathrm{R}_{3} \mathrm{SiH}$ hydrogen abstraction and $\mathrm{R}_{3} \mathrm{Si}^{\circ} / \mathrm{PC}^{\circ+}$ interaction, respectively and the $\mathrm{PC}$ is regenerated. Both initiating radicals $\left(\mathrm{R}_{3} \mathrm{Si}^{\bullet}\right)$, and cations $\left(\mathrm{R}_{3} \mathrm{Si}^{+}\right)$or radical cations $\left(\mathrm{PC}^{\cdot+}\right)$ are still formed (Scheme 5). In $\mathrm{PC} \mathrm{Ph}_{2} \mathrm{I}^{+} / \mathrm{NVK}, \mathrm{Ph}^{\cdot}$ reacts on the $\mathrm{NVK}$ double bond and the resulting electron rich NVK derived radical is oxidized by $\mathrm{Ph}_{2} \mathrm{I}^{+} / \mathrm{or} \mathrm{PC}^{\cdot+} .^{[15 \mathrm{a}, 38]}$ These threecomponent systems behave as efficient dual sources of radicals and cationic species for free radical polymerization $\mathrm{FRP}$, cationic polymerization $\mathrm{CP}$, free radical promoted cationic polymerization FRPCP, and for a concomitant radical/cationic polymerization CRCP for the access to interpenetrating polymer networks. ${ }^{[16]}$

Scheme 5. Reaction mechanisms for the $\mathrm{PC} / \mathrm{Ph}_{2} \mathrm{I}^{+} / \mathrm{R}_{3} \mathrm{SiH}$ system.

Various experimental conditions (UV/visible lights, monochromatic/polychromatic lights, high/low intensity, thin/thick films, high/low viscosity media, aerated/de-aerated conditions...) can be used. ${ }^{[10 a, 39]}$ Trends of development are obviously tightly linked to the application areas. In this optic, the photocatalytic systems must ensure: i) a visible light absorption depending on the PCs, ii) the possible use of polychromatic lights (lamps) or monochromatic lights (LEDs, laser diodes), ranging from the UV to the green (sometimes up to the red), even delivered by low light intensity sources such as sun or household devices, iii) the generation of radicals, radical cations or cations whatever the absorbing compound (the FRP, CP and FRPCP reactions as well as CRCP of acrylate/epoxide blends, ${ }^{[40]}$ or thiol-ene polymerization $^{[41]}$ under $10-100 \mathrm{~mW} / \mathrm{cm}^{2}$ irradiation in the visible wavelength range becoming feasible), iv) a more or less partial recovery of the PC, v) the search for more efficient photocatalytic systems through the use of novel additives (leading to more reactive 
initiating species), vi) the quest for photocatalytic systems less sensitive to the oxygen inhibition (e.g. silane derivatives present a beneficial effect towards the oxygen inhibition), ${ }^{[42]}$ vii) the design of more reactive PCs through a careful modification of existing structures or the proposal of innovative novel architectures, viii) the introduction of suitable substituents for enhanced properties (handling, solubility, (bio)compatibility, extractability, hydrophobicity/hydrophilicity, low migration...).

The PCs can be metal based photocatalysts (MPC) e.g. ruthenium, iridium, platinum, copper or iron complexes or metal free organic photocatalysts (OPC) e.g. organic dyes (methylene blue) or poly-aromatic compounds. Despite numerous works aiming at restricting the use of MPCs to avoid metal residues in the final polymers, only a few OPCs are known. [20b]

\section{3b) Metal-based photocatalysts MPCs}

Metal-based photocatalysts MPCs are today widely used in photocatalysis because they present excellent visible-light absorptions, long lived excited states, suitable redox potentials associated with good reversibility (for favourable electron transfer reactions) as well as large possibilities of ligand modifications that allow tuneable absorptions from the UV to the red LED irradiation wavelength. 


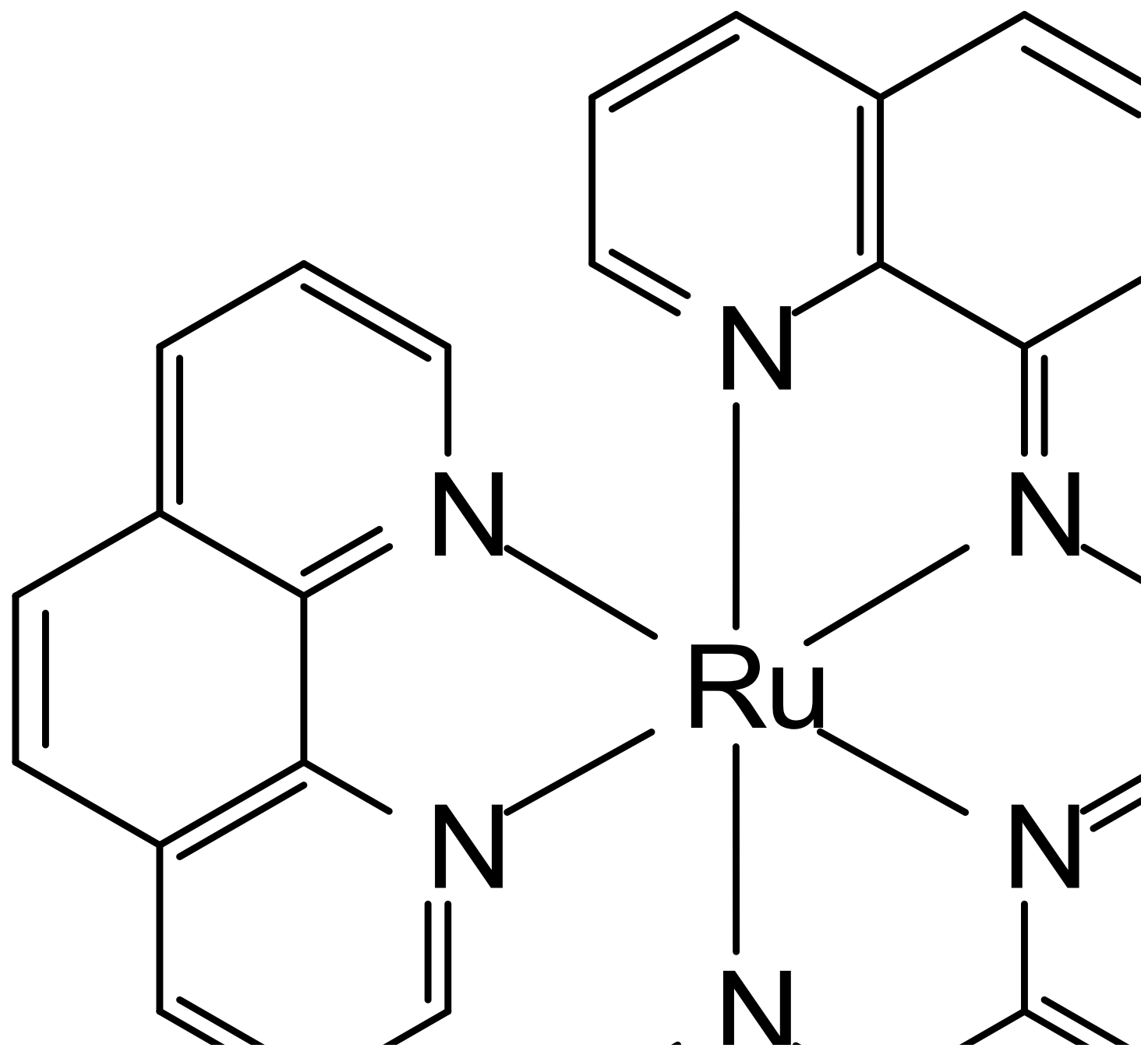

Figure 3. Ruthenium, iridium, platinum, copper and iron photocatalysts in polymerization.

The ruthenium and iridium MPCs (as exemplified in Figure 3) can react via an oxidative mechanism when they are included in a $\mathrm{PC} / \mathrm{Ph}_{2} \mathrm{I}^{+} / \mathrm{R}_{3} \mathrm{SiH}$ system ${ }^{[43]}$ (Scheme 5) or, on the opposite, can operate via a reductive pathway, are operative through an reductive cycle where they are included the MPC/AH/alkyl halide system (Scheme 4). ${ }^{[20 c, 44]}$

Finally $\mathrm{Ru}(\mathrm{II})$ and $\mathrm{Ir}(\mathrm{III})$ complexes have shown high activities for the FRP of acrylates, ${ }^{[20 \mathrm{c}, 43 \mathrm{a}]}$ the $\mathrm{CP}$ of epoxides, ${ }^{[44 \mathrm{c}, 45]}$ the FRPCP of $N$-vinylcarbazole, ${ }^{[38]}$ epoxides or renewable cationic monomers. ${ }^{[44 c]}$

Usual Ir and Ru-based complexes present a rather weak visible absorption. Incorporation of selected ligands (Figure 3) led to both a better reactivity and longer wavelength absorptions. ${ }^{[18 b, 20 c]}$ The reactions were carried out upon exposure to various visible sources (Xe lamps, LEDs, laser diodes, household halogen lamps and fluorescent 
bulbs, even sun...) from the UV to the red. Low light intensities and low viscosity media are usable. Typically, monomers in $25 \mu \mathrm{m}$ aerated films or in laminate conditions were easily polymerized.

Presenting long triplet state lifetimes and high visible-light absorptions, platinum complexes are very promising photocatalysts for polymerization (Figure 3). Recent works highlighted the high performances of the three-component system $\mathrm{Pt}(\mathrm{II})$ complex/silane/iodonium salt under visible irradiation for both radical and cationic polymerizations (Scheme 5) of acrylate and epoxide monomers, respectively. ${ }^{[46]}$

Beside the high photocatalytic activities of $\mathrm{Ru}$, Ir or Pt complexes, low cost metal complexes including iron, ${ }^{[47]}$, copper, ${ }^{[47 \mathrm{~b}]}$ zinc $^{[48]}$ and titanium ${ }^{[49]}$ have received an increasing interest. ${ }^{[20 \mathrm{~b}]}$ Indeed, $\mathrm{Cu}$ and $\mathrm{Fe}$ complexes are well known catalysts in atom transfer radical polymerization ATRP (see below) ${ }^{[50]}$ but recently their photocatalytic properties have been highlighted in free radical and cationic photopolymerization. ${ }^{[47 b, 51]}$ The copper complexes bearing a bis(2-(diphenylphosphino)phenyl)ether chelate (Figure 3), to enhance their excitedstate lifetimes, ${ }^{[52]}$ presented unprecedented photocatalytic activities in photopolymerization of acrylate and epoxide monomers using visible LEDs. ${ }^{[53]}$ Even their low excited state lifetime ${ }^{[54]}$ the iron complexes bearing iminopyridyl ligands (Figure 3) acted as efficient redox photocatalysts in $\mathrm{FRP},{ }^{[55]}$ in particular when photo-sensitive functions such as pyrene were linked to the ligands (Figure 3). ${ }^{[20 a]}$ More interestingly, in the presence of sacrificial electron donor such as amine (Scheme 4), a living character was observed for the acrylates and methacrylates radical polymerization using iron-based PCs (see below). ${ }^{[20 a]}$

Following a different photo-activation mechanism than redox catalysts, arene-type or carbene-type ruthenium complexes were effective PCs of ring opening metathesis polymerization under UV. ${ }^{[56]}$ In that case, the redox potential of the metal centers was not the key point of the activation but the irradiation induced coordination modifications, such as ligand elimination ${ }^{[57]}$ or reductive elimination, ${ }^{[58]}$ which generated the active catalytic species and initiated the olefin polymerization. ${ }^{[59]}$

\section{3c) Organophotocatalysts (OPCs) based systems}

The development of metal-free organophotocatalysts $\mathrm{OPCs}^{[60]}$ is currently a very important issue in order to restrict the utilization of metal-based PCs which are expensive, rather toxic and must be removed from the synthesized polymer. Two families of OPCs were mainly reported in photopolymerization: the organic dyes and the polyaromatic compounds. 
Organic dyes are widely exploited in three-component polymerization systems ${ }^{[16]}$ but their short-term storage stability ${ }^{[61]}$ and their degradability during the polymerization process $^{[62]}$ limits their utilization in catalytic amounts. The methylene blue $\mathrm{MB}^{+} / \mathrm{amine} /$ iodonium salt combination is a well-known system to generate phenyl radicals for FRP through the reductive quenching of excited state $\mathrm{MB}^{+*}$ with the amine (scheme 6$) .{ }^{[63]}$ More interestingly, an elegant work has reported the FRP of (meth)acrylates initiated by this visible-light three-component system via an organic photoredox catalytic mechanism. ${ }^{[64]}$ Moreover, the authors discovered that the polymerization can extend beyond the irradiation area and even after very long times. The originality consisted in the formation of the closedshell leuco-methylene blue (LMB) by two-electron transfer and one proton from the degradation of the sacrificial sterically-hindered diisopropylethylamine (DIPEA, Scheme 6) under visible light. ${ }^{[64]}$ Then, when the light was switched off, LMB slowly reacted with iodonium salt to liberate phenyl radicals to initiate the FRP of methyl methacrylate MMA (Scheme 6) and the dye was regenerated. Therefore, this system allowed the storage of light energy in a metastable closed-shell species (LMB) and an energy release in the dark. In addition, the polymerization of thick coatings was shown. ${ }^{[64]}$

Scheme 6. Reaction mechanisms for the $\mathrm{MB}^{+} / \mathrm{DIPEA} / \mathrm{Ph}_{2} \mathrm{I}^{+}$system.

Recently, polyaromatic compounds, e.g., pyrene derivatives, ${ }^{[65]}$ carbazole derivatives, ${ }^{[65-}$ 66] $N$-alkyl phenothiazine (H-PTZ, Me-PTZ, Figure 4), ${ }^{[66]}$ naphtacene, ${ }^{[18 a]}$ bis[(triisopropyl)silyl]-anthracene (Anth- $\left.\mathrm{Si}_{2}\right),{ }^{[66-67]}$ bis[(triisopropyl)silyl]pentacene (Pent$\left.\mathrm{Si}_{2}\right),{ }^{[18 \mathrm{a}]}$ truxene derivatives ${ }^{[40,68]}$ and triazine derivatives (Figure 4$),{ }^{[65,69]}$ have been proposed as OPCs for polymer synthesis. 


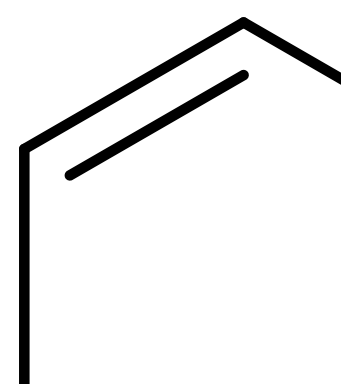

Figure 4. Organic photocatalysts (OPCs) for photopolymerization reactions.

In most cases, hydrocarbon derivatives included in a $\mathrm{OPC} / \mathrm{Ph}_{2} \mathrm{I}^{+} / \mathrm{R}_{3} \mathrm{SiH}$ system operated through an oxidation cycle (Scheme 5) to liberate $\mathrm{R}_{3} \mathrm{Si}^{+}$initiators for the ring-opening polymerization of epoxides. ${ }^{[40,67]}$ In addition, following a reduction cycle, these compounds included in the OPC/AH/alkyl halide (e.g. Phen-Br) system were able to generate phenacyl radicals and consequently to initiate the FRP of acrylate monomers. ${ }^{[18 \mathrm{a}]}$ Moreover, a careful 
modification of their $\pi$-hydrocarbon backbone allowed a tunable absorption over the whole visible range thus their sensitivity to light emitted by soft irradiation sources. ${ }^{[18 \mathrm{a}]}$

Less common, some polyaromatic compounds included in the OPC/AH/alkyl halide (e.g. Phen-Br) system work through an oxidation cycle. This is the case for truxeneacridinedione Tr-AD (Figure 5B). This mechanism was elucidated by spin-trapping EPR experiments which showed the formation of a high concentration of phenacyl radicals $\left(\mathrm{PhC}(\mathrm{O}) \mathrm{CH}_{2}{ }^{\bullet}\right)$ species when a mixture of $\mathrm{Tr}-\mathrm{AD}, \mathrm{Phen}-\mathrm{Br}$ and an amine (ethyldimethylaminobenzoate, EDB) was irradiated in the presence of phenyl- $N$-tertbutylnitrone (PBN, Figure 5A) ${ }^{[68]}$ The study concluded that the interaction of excited state Tr-AD with the alkyl halide was much more favourable than its interaction with the amine. ${ }^{[68]}$

A.

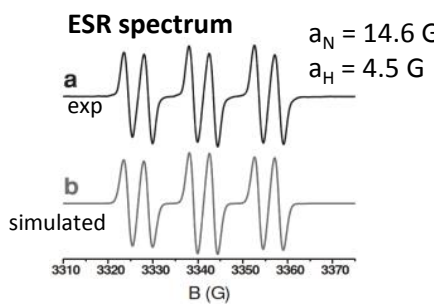

B.

Figure 5. A. spin trapping ESR experiments of Tr-AD/Phen-Br/EDB under irradiation and B. the proposed photocatalytic polymerization mechanism.

\section{4- Photocatalysts (PCs) in controlled radical photopolymerization reactions}

\section{4a) Controlled Radical PhotoPolymerization (CRP2)}

The control of the radical polymerization is a major issue for the macromolecular engineering in order to produce polymers with (i) a narrow mass distribution, (ii) a predicable molar mass, (iii) to preserve the chain-end fidelity, (iv) re-initiation properties for the access to complex architectures (block co-polymers ...). ${ }^{[70]}$ During the radical polymerization side reactions, leading to polymer death, occur such as polymer radical coupling or polymer radical dismutation. ${ }^{[70 \mathrm{a}, 70 \mathrm{~b}]}$ To avoid such reactions, a radical trapping agent is added to react with the growing polymer chains affording the dormant species but, to maintain the living polymerization, this reaction must be reversible. ${ }^{[71]}$ The main CRP processes are Atom transfer radical polymerization ATRP, ${ }^{[72]}$ nitroxide mediated polymerization NMP, ${ }^{[70 b]}$ reversible-fragmentation chain transfer RAFT, ${ }^{[73]}$ Organometallic radical mediated 
polymerization OMRP, ${ }^{[70 a, 74]}$ Iodine-Transfer Polymerization ITP $^{[75]}$ and Tellurium mediated radical polymerization TERP. ${ }^{[76]}$ While these CRP processes adopt very different chemical strategies, the balance between de-activation of radical chains and re-activation of the dormant species remains the main issue of the CRP. The thermal activation is the most efficient mode to liberate the radical polymer chains from the dormant species but this method is far to be universal since the temperature has a high impact on the polymerization rates and high temperatures, required to re-activate very stable dormant species, generate the degradation of the polymers, the monomers and the controlling agents. ${ }^{[10 \mathrm{j}, 77]}$

CRP2 appears to be a unique approach to the access to new radical polymerization conditions (low temperature, spatial control, sun light irradiation, utilization of photocatalysts, ....). ${ }^{[8 \mathrm{a}, 10 \mathrm{j}, 20 \mathrm{~d}, 78]}$ Since a photon source is required to reactivate the dormant species, light irradiations act as an "on/off" director ${ }^{[77,79]}$ for a temporal control of the polymerization and giving access to multilayer materials. ${ }^{[20 a]}$ Moreover, CRP2 is a powerful tool for spatial control, surface (micro)patterning, grafting and surface modifications since the polymerization can be precisely reinitiated only under the light irradiated area. ${ }^{[10 \mathrm{j}, 80]} \mathrm{CRP} 2$ can be an unique technique to combine the advantages of CRP processes (presence of dormant species) to those of photochemical reactions.

\section{4b) ATRP}

ATRP is based on the reversible halide termination of the radical active species. ${ }^{[72 b, 81]}$ The atom transfer agent liberates the radical species by trapping this halide. The most efficient atom transfer agents are the copper complexes. ${ }^{[82]}$ The recent advances in ATRP allow to regenerate the initial $\mathrm{Cu}(\mathrm{I})$ atom transfer agent using reducing agents without affecting the control of the radical polymerization and so, in others words, to use the $\mathrm{Cu}(\mathrm{I})$ atom transfer agent as a ATRP catalyst. ${ }^{[83]}$

More interestingly, copper complexes present highly interesting photophysical properties already exploited in photocatalysis. ${ }^{[84]}$ The first photo-activity of a copper center in a ATRP process was described in the beginning of the 2000, and the authors observed higher polymerization rates with narrow dispersities for MMA polymerization performed under visible irradiation than in the dark. ${ }^{[85]}$ The results inspired new ways in Photo-ATRP with $\mathrm{Cu}(\mathrm{I})$ complexes as controlling agents in presence of an alkyl dithiocarbamate. ${ }^{[86]}$

Different chemical mechanisms can be involved probably affected by the ligand in the $\mathrm{Cu}$ complex. For example, the oxidation of $\mathrm{Cu}(\mathrm{I})$ by $\mathrm{R}-\mathrm{Br}$ has been proposed in an oxidative 
catalytic cycle. ${ }^{[87]}$ But the Photo-ATRP can also be directed by the reduction of the $\mathrm{Cu}(\mathrm{II}) \mathrm{Br}_{2} / \mathrm{L}$ species $(\mathrm{L}=$ ligand) at the excited state under $\mathrm{UV}$ or visible irradiation and follows two mechanisms: (i) reductive elimination of a halide radical or (ii) oxidation of a sacrificial electron donor, in particular aliphatic amine derivatives ${ }^{[88]}$ or methanol. ${ }^{[89]}$ While the $\mathrm{Br}-\mathrm{Cu}(\mathrm{II})$ homolytic bond photo-cleavage was suggested in the literature, ${ }^{[79,90]}$ further investigations, performed by experimental and kinetic models, showed that this pathway is probably not favorable. ${ }^{[91]}$ The regeneration of $\mathrm{Cu}(\mathrm{I})$ activators via oxidation of amines was clearly established by combining pulsed-laser polymerization and high resolution mass spectroscopy ${ }^{[92]}$ and is consistent with the activators regenerated by electron-transfer (ARGET) ATRP process. ${ }^{[91]}$ This mechanism explained the excess of amine ligands required to maintain the radical polymerization since a part of the ligands is oxidized during the photoprocess. ${ }^{[93]}$ Moreover, the radical species resulting of the amine oxidation can act as polymerization initiators or regenerating agents in an ICAR ATRP pathway (Scheme 7). In addition, the in-situ photo-reduction of $\mathrm{CuBr}_{2}$ to $\mathrm{Cu}(\mathrm{I})$ atom transfer agent in the presence of amine $^{[88 \mathrm{a}, 93-94]}$ or, more recently, sodium formate ${ }^{[95]}$ is an elegant strategy to initiate the ATRP polymerization of various monomers including methacrylate or acrylate without the addition of air sensitive $\mathrm{Cu}(\mathrm{I})$ complexes and at low temperature. For a greener approach of the photoATRP, the CRP2 of oligo(ethylene oxide) methyl ether methacrylate was conducted with success in solution in water using ppm concentrations of copper catalyst and under a $392 \mathrm{~nm}$ wavelength irradiation. ${ }^{[96]}$

In another way, photo-initiators ${ }^{[78 b}$, 97$]$ or more interestingly organic photo-redox catalysts such as eosin $\mathrm{Y}^{[98]}$ can be used to initiate a photo-induced ICAR ATRP process but in that case the copper center cannot be considered as a real photo-active catalyst. ${ }^{\text {[9] }}$ 
Scheme 7. Example of mechanisms for the photoinduced $\mathrm{Cu}$-based ATRP.

While copper complexes are efficient catalysts for ATRP, iron complexes are up-andcoming controlling agent in ATRP since they are inexpensive, abundant and non-toxic. ${ }^{\text {[50, } 50 \mathrm{~b}]}$ ATRP mechanisms using iron complexes are very similar to copper ATRP, ${ }^{[50 a, 50 b]}$ allowing the utilization of catalytic amounts of iron controlling agents via ICAR ATRP or AGET ATRP and also via generation of activators by monomer addition GAMA ATRP. ${ }^{[100]}$ But, in contrast to copper complexes, iron complexes usually present a low excited state lifetime ${ }^{[54]}$ which is a dramatic limitation for application in photocatalysis. On the other hand, the CRP of MMA from the in-situ photo-reduction of $\mathrm{FeBr}_{3}$ to $\mathrm{FeBr}_{2}$ initiator was also reported; this latter reaction is associated with the formation of $\mathrm{BrCH}_{2} \mathrm{CMeBrCO}_{2} \mathrm{Me}$ under $\mathrm{UV}$ irradiation (Scheme 8). ${ }^{[101]}$ In addition, the CRP of MMA was achieved by photo-induced AGET ATRP using a $\mathrm{FeCl}_{3}$ /bipyridine complex and methanol or ethanol as reductive agent under UV. ${ }^{[102]}$ Recent articles reported the CRP of methacrylate using catalytic amounts of iron(II) complexes under visible irradiation. For instance, iron complexes bearing bipyridine ${ }^{[55]}$ or iminopyridine ligands (see Figure 3$)^{[20 \mathrm{a}]}$ induced a CRP process of methacrylate monomers and allowed the synthesis of PMMA- $b$-P(benzyl methacrylate) or PMMA- $b$ - P(butyl acrylate) bloc copolymers, respectively. Moreover, controlled surface patterning has been made possible using $\mathrm{Fe}(\mathrm{II})$-iminopyridine complexes as CRP photocatalysts. ${ }^{[20 \mathrm{a}]}$ 
Scheme 8. Photoinduced $\mathrm{FeBr}_{3}$-based ATRP.

Very recently the family of photo-redox metal catalysts for ATRP was enlarged to gold complexes. Having a low redox potential at the excited state, a dinuclear gold complexes proved to be a versatile catalyst able to control the radical polymerization of various monomers including methacrylates, triacrylates and fluorinated acrylates under UV or visible light. $^{[103]}$

\section{4c) RAFT}

The development of reversible-fragmentation chain transfer RAFT afforded a great impulse to controlled radical polymerization and gave access to large families of new polymeric materials. ${ }^{[73 a]}$ RAFT polymerization is based on the degenerative chain transfer operating on dithiocarbonate (a), xanthate (b), dithiocarbamate (c) or trithiocarbonate (d) as controlling agents, in the presence of a slight excess of radical species. ${ }^{[73 \mathrm{c}]}$

Very recently, an elegant and powerful methodology for CRP2 by photoelectron transfer RAFT (PET-RAFT) has been proposed. ${ }^{[104]}$ This strategy allows the polymerization without addition of radical since the RAFT controlling agent is temporary neutralized by electron transfer from a photocatalyst (Scheme 9). ${ }^{[104-105]}$ The high absorbance under blue LED sources (435 or $460 \mathrm{~nm}$ ) and the high reduction potential of Iridium or Ruthenium complexes made them very efficient photocatalysts for PET-RAFT with various RAFT agents. ${ }^{[106]}$ PET-RAFT permitted to control the radical polymerization of a wide range of monomers in particular unconjugated monomers such as vinyl esters and $N$-vinylpyrrolidone with a high tolerance to oxygen. ${ }^{[107]}$ Organic dyes, namely rhodamine, fluorescein, eosin Y, nile red, methylene blue, 4-cyanopentanoic acid dithiobenzoate or 10-phenylphenothiazine (Ph-PTZ, Figure 4), were evaluated as photocatalysts in PET-RAFT under soft irradiation LEDs $(461,530 \text { or } 635 \mathrm{~nm} \mathrm{LED)})^{[108]}$ or fluorescent lamp. ${ }^{[109]}$ Moreover, PET-RAFT using 
eosin $\mathrm{Y}$ proved to be air tolerant in the presence of triethylamine as electron sacrificial donor. ${ }^{[108]}$ Markedly in that case, eosin $\mathrm{Y}$ induced a reductive pathway and generated the $\mathrm{Et}_{3} \mathrm{~N}^{\bullet+}$ radical cation and the $\mathrm{EY}^{*-}$ species which finally reacted with dissolved oxygen. ${ }^{[108]} \mathrm{In}$ the optic to achieve CRP under very soft irradiations $(635 \mathrm{~nm})$, a zinc(porphyrin) complex, ${ }^{[110]}$ was an efficient photocatalyst for PET-RAFT under mild conditions. Moreover, a thiocarbonylthio RAFT agent bearing a porphyrin group led an efficient donor-acceptor photoredox catalyst for PET-RAFT under green and red LED with better performances (i.e. higher polymerization rate) than the RAFT agent associated with a free porphyrin photocatalyst. ${ }^{[11]}$ A green expansion of the PET-RAFT was the utilization of chlorophyll as photocatalyst to perform the CRP of various monomers (acrylates, methacrylates, $\mathrm{N}$ alkylacrylamides) under a $635 \mathrm{~nm}$ irradiation. ${ }^{[12]}$ Ultimately, new levels of CRP2 were accomplished when the PET-RAFT was achieved under far-red $(780 \mathrm{~nm})$ or near-infrared $(850 \mathrm{~nm})$ and low light intensity (up to $5 \mathrm{~mW} / \mathrm{cm}^{2}$ ) using bio-photocatalysts bacteriochlorophyll $a .^{[113]}$ These results open new perspectives for polymerization in biological media which required deep penetrating and non-destructive light irradiation.

Finally, the utilization of PET-RAFT techniques with Ir or Ru photocatalysts permitted to expand the CRP in aqueous media, ${ }^{[114]}$ in particular for miniemulsion polymerization ${ }^{[115]}$ and in organic dispersion to prepare polymer nanoparticles by polymerization-induced selfassembly ${ }^{[116]}$ under visible irradiations.

Definitively PET-RAFT using photocatalysts is a great extension of the RAFT process, ${ }^{[117]}$ providing significant advantages such as the absence of additional sources of radical initiator, high activities with minimal concentrations of PCs, low temperature reactions, a spatial and temporal control of the polymerization and the first near-infrared-CRP2 process. ${ }^{[13]}$

Scheme 9. Photoelectron transfer reversible-fragmentation chain transfer PET-RAFT. 


\section{4d) Photo-redox catalysts induced CRP}

Beyond the expansion of ATRP or RAFT processes into Photo-induced CRP under UV or visible irradiation, the literature shows that Photo-redox catalysts can also directly induce CRP.

Recently, the high performances of Ir complexes in CRP of methacrylate or acrylate monomers under UV or visible irradiations were demonstrated. ${ }^{[18]}$ The authors suggested that $\operatorname{Ir}(\text { ppy })_{3}$, at the excited state, reacted with alkyl-bromide dormant species (Scheme 10). Remarkably, to induce a controlled radical polymerization, the first step of the photocatalytic cycle must be the reaction between the $\operatorname{Ir}(\mathrm{III})$ complex at the excited state and the alkyl-halide initiator via an oxidative pathway (Scheme 3) to liberate the active radical species and to afford a Ir(IV)-Br intermediate (Scheme 10). ${ }^{[19]}$ This mechanism, oxidative $v s$ reductive, was suggested from spin-trapping ESR experiments and it is directed by the redox potential of the excited-state $\operatorname{Ir}(\mathrm{III})^{*}$ species, which is dramatically affected by the ligands, and the choice of the alkyl-Br radical initiator. ${ }^{[119]}$ The remarkable activities of $\operatorname{Ir}(\mathrm{ppy})_{3}$ in photo-CRP allowed the surface patterning of poly(MMA) controlled by the visible light irradiation, ${ }^{[120]}$ sequenced polymerization of fluorinated methacrylate monomers, ${ }^{[121]}$ in particular using perfluoro-1iodohexane as initiator, ${ }^{[122]}$ and sequenced polymerization of functional methacrylate monomers in-situ synthesized by enzymatic-catalysed reactions. ${ }^{[123]}$ In the latter case, beside the high performances of Ir(III)-based CRP under soft conditions, the authors noticed that key parameters such as the light intensity, the irradiation source, the $\operatorname{Ir}(\mathrm{III})$ concentration and residual compounds affected the CRP results. ${ }^{[24]}$ Finally the $\operatorname{Ir}(\mathrm{III})$ photo-induced CRP technology was expanded to the production of poly(MMA) in continuous flow microreactors under UV. ${ }^{[125]}$

In parallel of the emerging applications of organic photo-redox catalysts in synthesis, the high performances of organic dyes in metal-free (MF) ATRP were also demonstrated. ${ }^{[78 d \text {, }}$ ${ }^{126]}$ For instance 10-pheylphenothiazine (Ph-PTZ, Figure 4), at the excited state under UV irradiation, induced the liberation of radical active species via a dissociative electron-transfer reaction and the formation of a $\mathrm{Ph}-\mathrm{PTZ}^{-+} \mathrm{Br}^{-}$intermediate (Scheme 10) ${ }^{[66]}$ which then reacted with radical chains (Scheme 10), leading to the controlled polymerization of both methacrylate and acrylate monomers. ${ }^{[126-127]}$ Density functional theory (DFT) calculations suggested that the relative high stability of the $\mathrm{Ph}^{-} \mathrm{PTZ}^{++} \mathrm{Br}^{-}$intermediate is required to generate active radical from the alkyl-bromide and $\mathrm{Ph}-\mathrm{PTZ}^{*}$ but the deactivation step (formation of $\mathrm{P}_{n}$ - $\mathrm{Br}$, Scheme 10) seems to follow an associative electron transfer between the $\mathrm{Ph}-\mathrm{PTZ}^{\circ+}$ radical action, the bromide anion and the radical active species (Scheme 10). ${ }^{[66]}$ The 
recent studies have shown that phenothiazine bearing $N$-aryl substituents ( $P$-substituted phenyl groups, pyridine or naphthalene) were efficient MF ATRP catalysts of MMA polymerization because, under UV, they generated 1) a high reducing excited state $\mathrm{PC}^{*}$ and 2) a long life time $\mathrm{PC}^{\bullet+}$ species with a strong reduction potential to allow the deactivation of radical active species. ${ }^{[66]}$ Finally the scope of monomers controlled by MF ATRP under UV was widened to acrylonitrile using phenylphenothiazine derivatives. ${ }^{[128]}$

Recently, new perspectives to MF ATRP under visible irradiation have been opened for the CRP of MMA using perylene as organic photocatalyst. ${ }^{[129]}$

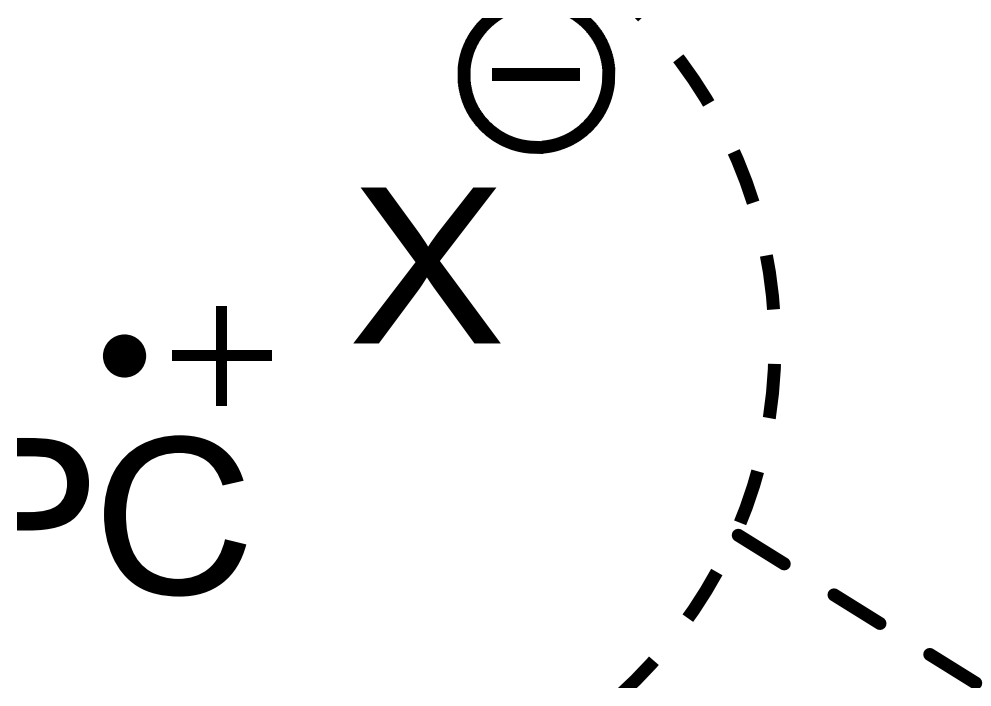

Scheme 10. Controlled radical polymerization using photo-redox catalysts.

\section{4e) Other CRP2 approaches}

Few years ago, pioneer articles described the reversible complexation mediated living radical polymerization RCMP of MMA where an organo-catalyst, in particular an amine, was able to liberate the radical polymer chains from alkyl-iodide dormant species. ${ }^{[130]}$ Recently, this technique has received a new direction to photo-RCMP since various amino-catalysts were able to activate the iodide-alkyl dormant species over a huge range of irradiation wavelengths $(350-750 \mathrm{~nm})$ and to mediate the polymerization of methacrylates (Scheme 10). ${ }^{[131]}$ In addition tertiary amines can act as photo-redox catalysts in RAFT processes under mild UV irradiation. ${ }^{[132]}$

Dimanganese decacarbonyl $(\mathrm{CO})_{5} \mathrm{Mn}-\mathrm{Mn}(\mathrm{CO})_{5}$ was exploited as a radical source in a copper photo-ICAR ATRP under sunlight. ${ }^{[97 a]}$ In that case, $\mathrm{Mn}(\mathrm{CO})_{5}{ }^{\cdot}$ active radicals are generated by 
homolytic cleavage of the dinuclear complex induce by light. ${ }^{[133]}$ Moreover, $\mathrm{Mn}(\mathrm{CO})_{5}{ }^{*}$ species are also efficient activators in Iodine-Transfer Polymerization $\operatorname{ITP}^{[134]}$ and in particular for vinylidene fluoride monomers CRP. ${ }^{[135]}$ The ability of $\mathrm{Mn}(0)$ complexes to act as CRP photocatalysts has been established since the polymerization of vinyl acetate via ITP in the presence of a catalytic amount of $\mathrm{Mn}_{2}(\mathrm{CO})_{10}$ did not occur in the dark but led to a CRP process under visible light (“on/off” light regulation). ${ }^{[136]}$ Similarly, recent studies have shown that $\operatorname{Re}_{2}(\mathrm{CO})_{10}$ is also a promising photocatalyst for ITP of vinylidene fluoride monomers. ${ }^{[135 \mathrm{a}]}$

\section{5-Outlook}

The utilization of photocatalysts as initiators for radical and cationic polymerizations has been a leap forward the polymer synthesis regarding the significant decrease of activator concentrations currently required in the industrial processes. Furthermore, applied in numerous CRP reactions, the photocatalysts allowed a photo-control of the polymerization and gave access to low temperature activation modes to widen the range of monomers usable in macromolecular engineering.

The mechanistic investigations highlighted that the competition between the reductive and the oxidative pathway of the $\operatorname{Ir}(\mathrm{III})$ catalytic cycle directs the catalyst behavior, leading to free radical polymerization in the first case and controlled radical polymerization from the oxidative reaction of Ir complexes with alkyl-halide derivatives. These investigations have to be extended to the various photocatalytic systems for a better understanding of the mechanisms and to design more efficient catalysts for free radical/cationic polymerization or for CRP2. Despite the unprecedented CRP results obtained using Ir and Ru photocatalysts, the current developments have to be focused on the utilization of low cost and eco-compatible photocatalysts, in particular iron catalysts and organo-photocatalysts.

For environmental issues, the next generation of photocatalysts must be able to initiate polymerizations under ultra-soft irradiation, i.e. under low intensity red LED or near-infrared, and therefore will open new perspectives in medical applications for in-vivo polymerization (sutural gels, tissue scaffolds, bone prosthesis) by thiol-ene photopolymerization, complex coatings using high penetrating irradiations, industrial polymerization in complex systems such high pressure reactors and daily-life utilizations such as 3D printing. 


\section{6-References:}

[1] a) P. Glöckner, Radiation Curing: Coatings and Printing Inks ; Technical Basics, Applications and Trouble Shooting, Vincentz Network, 2008; b) J. P. Fouassier, J. F. Rabek, Radiation Curing in Polymer Science and Technology, Springer Science \& Business Media, 1993, 1993.

[2] Y. Tsujii, K. Ohno, S. Yamamoto, A. Goto, T. Fukuda, Adv. Polym. Sci. 2006, 197, 145.

[3] Y.-L. Zhang, Q.-D. Chen, H. Xia, H.-B. Sun, Nano Today 2010, 5, 435-448.

[4] a) B. D. Gates, Q. Xu, M. Stewart, D. Ryan, C. G. Willson, G. M. Whitesides, Chem. Rev. 2005, 105, 1171-1196; b) L. J. Guo, Adv. Mater. 2007, 19, 495-513; c) B.-J. de Gans, P. C. Duineveld, U. S. Schubert, Adv. Mater. 2004, 16, 203-213.

[5] A. Ibrahim, L. D. Stefano, O. Tarzi, H. Tar, C. Ley, X. Allonas, Photochem. Photobiol. 2013, 89, 1283-1290.

[6] R. Bachelot, C. Ecoffet, D. Deloeil, P. Royer, D.-J. Lougnot, Appl. Opt. 2001, 40, 5860-5871.

[7] N. Moszner, U. Salz, Macromol. Mater. Eng. 2007, 292, 245-271.

[8] a) Y. Yagci, S. Jockusch, N. J. Turro, Macromolecules 2010, 43, 6245-6260; b) J. L. Ifkovits, J. A. Burdick, Tissue Eng. 2007, 13, 2369-2385.

[9] a) J. P. Fouassier, J. Lalevée, Photoinitiators for Polymer Synthesis, Wiley-VCH, 2012; b) M. G. Ivan, J. C. Scaiano, Photoimaging and lithographic processes in polymers, John Wiley \& Sons, Inc., 2010.

[10] a) P. Xiao, J. Zhang, F. Dumur, M. A. Tehfe, F. Morlet-Savary, B. Graff, D. Gigmes, J. P. Fouassier, J. Lalevée, Prog. Polym. Sci. 2015, 41, 32-66; b) J. P. Fouassier, J. Lalevée, Photoinitiators for Polymer Synthesis: Scope, Reactivity, and Efficiency, John Wiley \& Sons, 2013; c) P. Vana, C. Barner-Kowollik, T. P. Davis, K. Matyjaszewski, Vol. 11, John Wiley \& Sons, Inc., 2014, pp. 501-614; d) J. Lalevée (Ed.), J.-P. Fouassier (Ed.), Dyes and Chomophores in Polymer Science, John Wiley \& Sons, Inc., 2015; e) K. Dietliker, A Compilation of Photoinitiators Commercially Available for UV Today, SITA Technology Limited, 2002; f) W. A. Green, Industrial Photoinitiators: A Technical Guide, Taylor \& Francis, 2010; g) J. V. Crivello, K. Dietliker, G. Bradley, Photoinitiators for Free Radical Cationic \& Anionic Photopolymerisation, John Wiley \& Sons, 1999; h) W. Schnabel, Polymers and Light: Fundamentals and Technical Applications, John Wiley \& Sons, 2007; i) S. P. Pappas, Prog. Org. Coat. 1985, 13, 35-64; j) S. Dadashi-Silab, S. Doran, Y. Yagci, Chem. Rev. 2016, DOI:10.1021/acs.chemrev.1025b00586.

[11] J. P. Fouassier, X. Allonas, D. Burget, Prog. Org. Coat. 2003, 47, 16-36.

[12] a) M. A. Tehfe, F. Louradour, J. Lalevée, J.-P. Fouassier, Appl. Sci. 2013, 3, 490-514; b) J.-P. Fouassier, F. Morlet-Savary, J. Lalevee, X. Allonas, C. Ley, Materials 2010, 3, 5130-5142.

[13] a) J. V. Crivello, J. Polym. Sci., Part A: Polym. Chem. 1999, 37, 4241-4254; b) S. Doran, G. Yilmaz, Y. Yagci, Macromolecules 2015, 48, 7446-7452.

[14] J. V. Crivello, U. Bulut, J. Polym. Sci., Part A: Polym. Chem. 2005, 43, 5217-5231.

[15] a) J. Lalevée, M.-A. Tehfe, A. Zein-Fakih, B. Ball, S. Telitel, F. Morlet-Savary, B. Graff, J. P. Fouassier, ACS Macro Lett. 2012, 1, 802-806; b) S. Aoshima, S. Kanaoka, Chem. Rev. 2009, 109, 5245-5287; c) A. J. Perkowski, W. You, D. A. Nicewicz, J. Am. Chem. Soc. 2015, 137, 7580-7583.

[16] J.-P. Fouassier, J. Lalevée, RSC Adv. 2012, 2, 2621-2629.

[17] J. Kabatc, K. Jurek, Polymer 2012, 53, 1973-1980.

[18] a) M.-A. Tehfe, J. Lalevée, F. Morlet-Savary, B. Graff, N. Blanchard, J.-P. Fouassier, Macromolecules 2012, 45, 1746-1752; b) J. Lalevée, M.-A. Tehfe, F. Morlet-Savary, 
B. Graff, F. Dumur, D. Gigmes, N. Blanchard, J.-P. Fouassier, Chimia 2012, 66, 439441.

[19] a) A. E. Allen, D. W. C. MacMillan, Chem. Sci. 2012, 3, 633-658; b) J. M. R. Narayanam, C. R. J. Stephenson, Chem. Soc. Rev. 2011, 40, 102-113; c) C. K. Prier, D. A. Rankic, D. W. C. MacMillan, Chem. Rev. 2013, 113, 5322-5363; d) T. P. Yoon, M. A. Ischay, J. Du, Nat. Chem. 2010, 2, 527-532; e) G. Palmisano, V. Augugliaro, M. Pagliaro, L. Palmisano, Chem. Commun. 2007, 3425-3437; f) J. W. Beatty, C. R. J. Stephenson, Acc. Chem. Res. 2015, 48, 1474-1484.

[20] a) S. Telitel, F. Dumur, D. Campolo, J. Poly, D. Gigmes, J. P. Fouassier, J. Lalevée, J. Polym. Sci. Part A 2015, AoP; b) J. Lalevée, S. Telitel, P. Xiao, M. Lepeltier, F. Dumur, F. Morlet-Savary, D. Gigmes, J.-P. Fouassier, Beilstein J. Org. Chem. 2014, 10, 863-876; c) J. Lalevée, M.-A. Tehfe, F. Dumur, D. Gigmes, N. Blanchard, F. Morlet-Savary, J. P. Fouassier, ACS Macro Lett. 2012, 1, 286-290; d) A. J. Teator, D. N. Lastovickova, C. W. Bielawski, Chem. Rev. 2015, DIO:10.1021/acs.chemrev.1025b00426.

[21] M.-A. Tehfe, J. Lalevée, D. Gigmes, J. P. Fouassier, J. Polym. Sci., Part A: Polym. Chem. 2010, 48, 1830-1837.

[22] S. Telitel, J. Lalevée, N. Blanchard, T. Kavalli, M.-A. Tehfe, S. Schweizer, F. MorletSavary, B. Graff, J.-P. Fouassier, Macromolecules 2012, 45, 6864-6868.

[23] a) K. Zeitler, Angew. Chem., Int. Ed. 2009, 48, 9785-9789; b) D. Ravelli, M. Fagnoni, ChemCatChem 2012, 4, 169-171.

[24] C. Dietlin, S. Schweizer, P. Xiao, J. Zhang, F. Morlet-Savary, B. Graff, J.-P. Fouassier, J. Lalevée, Polym. Chem. 2015, 6, 3895-3912.

[25] H. Imahori, T. Umeyama, S. Ito, Acc. Chem. Res. 2009, 42, 1809-1818.

[26] a) J. Yang, P. Ganesan, J. Teuscher, T. Moehl, Y. J. Kim, C. Yi, P. Comte, K. Pei, T. W. Holcombe, M. K. Nazeeruddin, J. Hua, S. M. Zakeeruddin, H. Tian, M. Gratzel, J. Am. Chem. Soc. 2014, 136, 5722-5730; b) A. Yella, C.-L. Mai, S. M. Zakeeruddin, S.N. Chang, C.-H. Hsieh, C.-Y. Yeh, M. Graetzel, Angew. Chem., Int. Ed. 2014, 53, 2973-2977.

[27] S. R. Marder, L. T. Cheng, B. G. Tiemann, A. C. Friedli, M. Blanchard-Desce, J. W. Perry, J. Skindhøj, Science 1994, 263, 511-514.

[28] T. B. Demissie, K. Ruud, J. H. Hansen, Organometallics 2015, 34, 4218-4228.

[29] D. P. Hari, B. König, Chem. Commun. 2014, 50, 6688-6699.

[30] N. J. Turro, V. Ramamurthy, J. C. Scaiano, Principles of Molecular Photochemistry: An Introduction, University Science Books, 2009.

[31] A. Jablonski, Nature 1933, 131, 839-840.

[32] M. El-Roz, J. Lalevée, X. Allonas, J. P. Fouassier, Macromolecules 2009, 42, 87258732.

[33] a) J. Lalevée, A. Dirani, M. El-Roz, X. Allonas, J. P. Fouassier, J. Polym. Sci., Part A: Polym. Chem. 2008, 46, 3042-3047; b) D. Neshchadin, A. Rosspeintner, M. Griesser, B. Lang, S. Mosquera-Vazquez, E. Vauthey, V. Gorelik, R. Liska, C. Hametner, B. Ganster, R. Saf, N. Moszner, G. Gescheidt, J. Am. Chem. Soc. 2013, 135, 1731417321.

[34] F. Castellanos, J. P. Fouassier, C. Priou, J. Cavezzan, J. Appl. Polym. Sci. 1996, 60, 705-713.

[35] K. A. Ogawa, A. E. Goetz, A. J. Boydston, J. Am. Chem. Soc. 2015, 137, 1400-1403.

[36] a) H.-W. Shih, M. N. Vander Wal, R. L. Grange, D. W. C. MacMillan, J. Am. Chem. Soc. 2010, 132, 13600-13603; b) D. A. Nicewicz, D. W. C. MacMillan, Science 2008, 322, 77-80; c) D. A. Nagib, M. E. Scott, D. W. C. MacMillan, J. Am. Chem. Soc. 2009, 131, 10875-10877; d) M.-H. Larraufie, R. Pellet, L. Fensterbank, J.-P. Goddard, 
E. Lacote, M. Malacria, C. Ollivier, Angew. Chem., Int. Ed. 2011, 50, 4463-4466; e) M. Neumann, S. Fueldner, B. König, K. Zeitler, Angew. Chem., Int. Ed. 2011, 50, 951-954; f) D. M. Schultz, T. P. Yoon, Science 2014, 343, 985; g) J. D. Nguyen, J. W. Tucker, M. D. Konieczynska, C. R. J. Stephenson, J. Am. Chem. Soc. 2011, 133, 4160-4163; h) T. Courant, G. Masson, Chem. - Eur. J. 2012, 18, 423-427.

[37] S. Maity, N. Zheng, Synlett 2012, 23, 1851-1856.

[38] J. Lalevée, F. Dumur, C. R. Mayer, D. Gigmes, G. Nasr, M.-A. Tehfe, S. Telitel, F. Morlet-Savary, B. Graff, J. P. Fouassier, Macromolecules 2012, 45, 4134-4141.

[39] P. Collery, A. Mohsen, A. Kermagoret, S. Corre, G. Bastian, A. Tomas, M. Wei, F. Santoni, N. Guerra, D. Desmaele, J. d'Angelo, Invest. New Drugs 2015, 33, 848-860.

[40] M.-A. Tehfe, J. Lalevée, S. Telitel, E. Contal, F. Dumur, D. Gigmes, D. Bertin, M. Nechab, B. Graff, F. Morlet-Savary, J.-P. Fouassier, Macromolecules 2012, 45, 44544460.

[41] a) M.-A. Tehfe, F. Dumur, P. Xiao, M. Delgove, B. Graff, J.-P. Fouassier, D. Gigmes, J. Lalevée, Polym. Chem. 2014, 5, 382-390; b) B. Fang, M. Jin, X. Wu, Y. Zhang, D. Wan, Dyes Pigm. 2016, 126, 54-61.

[42] S. C. Ligon, B. Husar, H. Wutzel, R. Holman, R. Liska, Chem. Rev. 2014, 114, 557589.

[43] a) J. Lalevée, M. Peter, F. Dumur, D. Gigmes, N. Blanchard, M.-A. Tehfe, F. MorletSavary, J. P. Fouassier, Chem. - Eur. J. 2011, 17, 15027-15031; b) S. Telitel, F. Dumur, M. Lepeltier, D. Gigmes, J.-P. Fouassier, J. Lalevée, C. R. Chim. 2015, DOI:10.1016/j.crci.2015.1006.1016.

[44] a) Y. Chen, Z. Hu, D. Xu, Y. Yu, X. Tang, H. Guo, Macromol. Chem. Phys. 2015, 216, 1055-1060; b) G. Zhang, I. Y. Song, K. H. Ahn, T. Park, W. Choi, Macromolecules 2011, 44, 7594-7599; c) J. Lalevée, N. Blanchard, M.-A. Tehfe, F. Morlet-Savary, J. P. Fouassier, Macromolecules 2010, 43, 10191-10195.

[45] J. Lalevée, N. Blanchard, M.-A. Tehfe, M. Peter, F. Morlet-Savary, J. P. Fouassier, Polym. Bull. 2012, 68, 341-347.

[46] M.-A. Tehfe, L. Ma, B. Graff, F. Morlet-Savary, J.-P. Fouassier, J. Zhao, J. Lalevée, Macromol. Chem. Phys. 2012, 213, 2282-2286.

[47] a) J. Zhang, D. Campolo, F. Dumur, P. Xiao, J. P. Fouassier, D. Gigmes, J. Lalevée, J. Polym. Sci. Part A 2015, 53, 42-49; b) P. Xiao, J. Zhang, D. Campolo, F. Dumur, D. Gigmes, J. P. Fouassier, J. Lalevée, J. Polym. Sci. Part A 2015, 53, 2673-2684.

[48] a) M.-A. Tehfe, F. Dumur, S. Telitel, D. Gigmes, E. Contal, D. Bertin, F. MorletSavary, B. Graff, J.-P. Fouassier, J. Lalevée, Eur. Polym. J. 2013, 49, 1040-1049; b) D. L. Versace, J. Bourgon, E. Leroy, F. Dumur, D. Gigmes, J. P. Fouassier, J. Lalevée, Polym. Chem. 2014, 5, 6569-6576.

[49] a) D.-L. Versace, J.-P. Fouassier, J. Lalevée, Macromol. Rapid Commun. 2014, 35, 821-826; b) M.-A. Tehfe, J. Lalevee, F. Morlet-Savary, B. Graff, J.-P. Fouassier, Macromolecules 2012, 45, 356-361.

[50] a) Z. Xue, D. He, X. Xie, Polym. Chem. 2015, 6, 1660-1687; b) R. Poli, L. E. N. Allan, M. P. Shaver, Prog. Polym. Sci. 2014, 39, 1827-1845; c) J.-S. Wang, K. Matyjaszewski, J. Am. Chem. Soc. 1995, 117, 5614-5615; d) M. Kamigaito, T. Ando, M. Sawamoto, Chem. Rev. 2001, 101, 3689-3745.

[51] a) J. Zhang, D. Campolo, F. Dumur, P. Xiao, D. Gigmes, J. P. Fouassier, J. Lalevée, Polym. Bull. 2016, 73, 493-507; b) P. Xiao, F. Dumur, J. Zhang, D. Gigmes, J. P. Fouassier, J. Lalevée, Polym. Chem. 2014, 5, 6350-6357.

[52] D. G. Cuttell, S.-M. Kuang, P. E. Fanwick, D. R. McMillin, R. A. Walton, J. Am. Chem. Soc. 2002, 124, 6-7. 
[53] P. Xiao, F. Dumur, J. Zhang, J. P. Fouassier, D. Gigmes, J. Lalevée, Macromolecules 2014, 47, 3837-3844.

[54] L. A. Fredin, M. Papai, E. Rozsalyi, G. Vanko, K. Waernmark, V. Sundstroem, P. Persson, J. Phys. Chem. Lett. 2014, 5, 2066-2071.

[55] A. Bansal, P. Kumar, C. D. Sharma, S. S. Ray, S. L. Jain, J. Polym. Sci., Part A: Polym. Chem. 2015, 53, 2739-2746.

[56] a) K. A. Ogawa, A. E. Goetz, A. J. Boydston, Synlett 2016, 27, 203-214; b) A. Hafner, A. Muhlebach, P. A. Van Der Schaaf, Angew. Chem., Int. Ed. Engl. 1997, 36, 21212124; c) L. Delaude, M. Szypa, A. Demonceau, A. F. Noels, Adv. Synth. Catal. 2002, $344,749-756$.

[57] D. Wang, K. Wurst, W. Knolle, U. Decker, L. Prager, S. Naumov, M. R. Buchmeiser, Angew. Chem., Int. Ed. 2008, 47, 3267-3270.

[58] D. Wang, J. Unold, M. Bubrin, W. Frey, W. Kaim, M. R. Buchmeiser, ChemCatChem 2012, 4, 1808-1812.

[59] Y. Vidavsky, N. G. Lemcoff, Beilstein J. Org. Chem. 2010, 6, 1106-1119.

[60] a) D. A. Nicewicz, T. M. Nguyen, ACS Catal. 2014, 4, 355-360; b) S. Fukuzumi, K. Ohkubo, Org. Biomol. Chem. 2014, 12, 6059-6071.

[61] B. M. Monroe, G. C. Weed, Chem. Rev. 1993, 93, 435-448.

[62] H. J. Avens, C. N. Bowman, J. Polym. Sci., Part A: Polym. Chem. 2009, 47, 60836094.

[63] a) K. S. Padon, A. B. Scranton, J. Polym. Sci., Part A: Polym. Chem. 2000, 38, 20572066; b) D. Kim, A. B. Scranton, J. W. Stansbury, J. Appl. Polym. Sci. 2009, 114, $1535-1542$.

[64] A. Aguirre-Soto, C.-H. Lim, A. T. Hwang, C. B. Musgrave, J. W. Stansbury, J. Am. Chem. Soc. 2014, 136, 7418-7427.

[65] S. Telitel, F. Dumur, T. Faury, B. Graff, M.-A. Tehfe, D. Gigmes, J.-P. Fouassier, J. Lalevée, Beilstein J. Org. Chem. 2013, 9, 877-890, No. 101.

[66] X. Pan, C. Fang, M. Fantin, N. Malhotra, W. Y. So, L. A. Peteanu, A. A. Isse, A. Gennaro, P. Liu, K. Matyjaszewski, J. Am. Chem. Soc. 2016, DOI:10.1021/jacs.1025b13455.

[67] M.-A. Tehfe, J. Lalevée, F. Morlet-Savary, B. Graff, N. Blanchard, J.-P. Fouassier, ACS Macro Lett. 2012, 1, 198-203.

[68] M.-A. Tehfe, F. Dumur, E. Contal, B. Graff, D. Gigmes, J.-P. Fouassier, J. Lalevée, Macromol. Chem. Phys. 2013, 214, 2189-2201.

[69] M.-A. Tehfe, F. Dumur, B. Graff, F. Morlet-Savary, J.-P. Fouassier, D. Gigmes, J. Lalevée, Macromolecules 2012, 45, 8639-8647.

[70] a) R. Poli, Chem. - Eur. J. 2015, 21, 6988-7001; b) J. Nicolas, Y. Guillaneuf, C. Lefay, D. Bertin, D. Gigmes, B. Charleux, Prog. Polym. Sci. 2013, 38, 63-235; c) W. A. Braunecker, K. Matyjaszewski, Prog. Polym. Sci. 2007, 32, 93-146.

[71] B. M. Rosen, V. Percec, Chem. Rev. 2009, 109, 5069-5119.

[72] a) K. Matyjaszewski, Macromolecules 2012, 45, 4015-4039; b) K. Matyjaszewski, N. V. Tsarevsky, J. Am. Chem. Soc. 2014, 136, 6513-6533; c) N. Zhang, S. R. Samanta, B. M. Rosen, V. Percec, Chem. Rev. 2014, 114, 5848-5958.

[73] a) G. Moad, E. Rizzardo, S. H. Thang, Chem. - Asian J. 2013, 8, 1634-1644; b) G. Moad, E. Rizzardo, S. H. Thang, Aust. J. Chem. 2012, 65, 985-1076; c) M. R. Hill, R. N. Carmean, B. S. Sumerlin, Macromolecules 2015, 48, 5459-5469.

[74] a) M. Hurtgen, C. Detrembleur, C. Jérôme, A. Debuigne, Polym. Rev. 2011, 51, 188213; b) A. Kermagoret, A. Debuigne, C. Jérôme, C. Detrembleur, Nat. Chem. 2014, 6, 179-187; c) A. Debuigne, R. Poli, C. Jérôme, R. Jérôme, C. Detrembleur, Prog. Polym. Sci. 2009, 34, 211-239; d) J. Demarteau, A. Kermagoret, I. German, D. 
Cordella, K. Robeyns, J. De Winter, P. Gerbaux, C. Jérôme, A. Debuigne, C. Detrembleur, Chem. Commun. 2015, 51 14334-14337.

[75] G. David, C. Boyer, J. Tonnar, B. Ameduri, P. Lacroix-Desmazes, B. Boutevin, Chem. Rev. 2006, 106, 3936-3962.

[76] a) S. Yamago, Chem. Rev. 2009, 109, 5051-5068; b) A. Kermagoret, Y. Nakamura, M. Bourguignon, C. Detrembleur, C. Jérôme, S. Yamago, A. Debuigne, ACS Macro Lett. 2014, 3, 114-118.

[77] F. A. Leibfarth, K. M. Mattson, B. P. Fors, H. A. Collins, C. J. Hawker, Angew. Chem., Int. Ed. 2013, 52, 199-210.

[78] a) S. Yamago, Y. Nakamura, Polymer 2013, 54, 981-994; b) S. Dadashi-Silab, M. Atilla Tasdelen, Y. Yagci, J. Polym. Sci., Part A: Polym. Chem. 2014, 52, 2878-2888;

c) N. Ballard, D. Mecerreyes, J. M. Asua, Chem. - Eur. J. 2015, 21, 18516-18527; d) J. T. Trotta, B. P. Fors, Synlett 2016, DOI:10.1055/s-0035-1561264.

[79] D. Konkolewicz, K. Schroder, J. Buback, S. Bernhard, K. Matyjaszewski, ACS Macro Lett. 2012, 1, 1219-1223.

[80] a) R. Barbey, L. Lavanant, D. Paripovic, N. Schuwer, C. Sugnaux, S. Tugulu, H.-A. Klok, Chem. Rev. 2009, 109, 5437-5527; b) B. de Boer, H. K. Simon, M. P. L. Werts, E. W. van der Vegte, G. Hadziioannou, Macromolecules 2000, 33, 349-356; c) S. Telitel, S. Telitel, J. Bosson, J. Lalevée, J.-L. Clément, M. Godfroy, J.-L. Fillaut, H. Akdas-Kilig, Y. Guillaneuf, D. Gigmes, O. Soppera, Langmuir 2015, 31, 1002610036; d) M. Kaholek, W.-K. Lee, S.-J. Ahn, H. Ma, K. C. Caster, B. LaMattina, S. Zauscher, Chem. Mater. 2004, 16, 3688-3696; e) A. S. Goldmann, G. Delaittre, J. O. Mueller, C. Barner-Kowollik, in Dyes and Chromophores in Polymer Science, John Wiley \& Sons, Inc., 2015, pp. 279-326.

[81] N. V. Tsarevsky, K. Matyjaszewski, Chem. Rev. 2007, 107, 2270-2299.

[82] a) T. E. Patten, K. Matyjaszewski, Acc. Chem. Res. 1999, 32, 895-903; b) C. Boyer, N. A. Corrigan, K. Jung, D. Nguyen, T.-K. Nguyen, N. N. M. Adnan, S. Oliver, S. Shanmugam, J. Yeow, Chem. Rev. 2015, DOI:10.1021/acs.chemrev.1025b00396.

[83] a) Y. Wang, N. Soerensen, M. Zhong, H. Schröder, M. Buback, K. Matyjaszewski, Macromolecules 2013, 46, 683-691; b) H. Tang, N. Arulsamy, M. Radosz, Y. Shen, N. V. Tsarevsky, W. A. Braunecker, W. Tang, K. Matyjaszewski, J. Am. Chem. Soc. 2006, 128, 16277-16285; c) T. Pintauer, K. Matyjaszewski, Chem. Soc. Rev. 2008, 37, 1087-1097; d) Q. Lou, D. A. Shipp, ChemPhysChem 2012, 13, 3257-3261.

[84] a) S. Paria, O. Reiser, ChemCatChem 2014, 6, 2477-2483; b) J. M. Kern, J. P. Sauvage, J. Chem. Soc., Chem. Commun. 1987, 546-548.

[85] Z. Guan, B. Smart, Macromolecules 2000, 33, 6904-6906.

[86] Y. Kwak, K. Matyjaszewski, Macromolecules 2010, 43, 5180-5183.

[87] Q. Yang, F. Dumur, F. Morlet-Savary, J. Poly, J. Lalevée, Macromolecules 2015, 48, 1972-1980.

[88] a) A. Anastasaki, V. Nikolaou, Q. Zhang, J. Burns, S. R. Samanta, C. Waldron, A. J. Haddleton, R. McHale, D. Fox, V. Percec, P. Wilson, D. M. Haddleton, J. Am. Chem. Soc. 2014, 136, 1141-1149; b) A. Baralle, L. Fensterbank, J.-P. Goddard, C. Ollivier, Chem. - Eur. J. 2013, 19, 10809-10813.

[89] M. A. Tasdelen, M. Uygun, Y. Yagci, Macromol. Chem. Phys. 2010, 211, 2271-2275.

[90] M. Ciftci, M. A. Tasdelen, W. Li, K. Matyjaszewski, Y. Yagci, Macromolecules 2013, 46, 9537-9543.

[91] T. G. Ribelli, D. Konkolewicz, S. Bernhard, K. Matyjaszewski, J. Am. Chem. Soc. 2014, 136, 13303-13312.

[92] E. Frick, A. Anastasaki, D. M. Haddleton, C. Barner-Kowollik, J. Am. Chem. Soc. 2015, 137, 6889-6896. 
[93] J. Mosnáček, A. Eckstein-Andicsová, K. Borská, Polym. Chem. 2015, 6, 2523-2530.

[94] a) T. Zhang, T. Chen, I. Amin, R. Jordan, Polym. Chem. 2014, 5, 4790-4796; b) M. A. Tasdelen, M. Uygun, Y. Yagci, Macromol. Rapid Commun. 2011, 32, 58-62; c) J. Mosnáček, M. Ilčíková, Macromolecules 2012, 45, 5859-5865; d) A. Anastasaki, V. Nikolaou, A. Simula, J. Godfrey, M. Li, G. Nurumbetov, P. Wilson, D. M. Haddleton, Macromolecules 2014, 47, 3852-3859; e) A. Anastasaki, V. Nikolaou, G. S. Pappas, Q. Zhang, C. Wan, P. Wilson, T. P. Davis, M. R. Whittaker, D. M. Haddleton, Chem. Sci. 2014, 5, 3536-3542.

[95] a) A. Anastasaki, V. Nikolaou, F. Brandford-Adams, G. Nurumbetov, Q. Zhang, G. J. Clarkson, D. J. Fox, P. Wilson, K. Kempe, D. M. Haddleton, Chem. Commun. 2015, 51, 5626-5629; b) V. Nikolaou, A. Anastasaki, F. Brandford-Adams, R. Whitfield, G. R. Jones, G. Nurumbetov, D. M. Haddleton, Polym. Chem. 2016, 7, 191-197.

[96] X. Pan, N. Malhotra, A. Simakova, Z. Wang, D. Konkolewicz, K. Matyjaszewski, J. Am. Chem. Soc. 2015, 137, 15430-15433.

[97] a) M. Ciftci, M. A. Tasdelen, Y. Yagci, Polym. Chem. 2014, 5, 600-606; b) S. Dadashi-Silab, M. A. Tasdelen, B. Kiskan, X. Wang, M. Antonietti, Y. Yagci, Macromol. Chem. Phys. 2014, 215, 675-681; c) Y. Yagci, M. A. Tasdelen, S. Jockusch, Polymer 2014, 55, 3468-3474.

[98] M. A. Tasdelen, M. Ciftci, Y. Yagci, Macromol. Chem. Phys. 2012, 213, 1391-1396.

[99] T. G. Ribelli, D. Konkolewicz, X. Pan, K. Matyjaszewski, Macromolecules 2014, 47, 6316-6321.

[100] a) Z. Xue, T. B. L. Nguyen, S. K. Noh, W. S. Lyoo, Angew. Chem., Int. Ed. 2008, 47, 6426-6429; b) D. He, Z. Xue, M. Y. Khan, S. K. Noh, W. S. Lyoo, J. Polym. Sci., Part A: Polym. Chem. 2010, 48, 144-151.

[101] X. Pan, N. Malhotra, J. Zhang, K. Matyjaszewski, Macromolecules 2015, 48, 69486954.

[102] G.-X. Wang, M. Lu, Z.-H. Hou, Y. Gao, L.-C. Liu, H. Wu, J. Macromol. Sci., Part A: Pure Appl. Chem. 2014, 51, 565-571.

[103] F. Nzulu, S. Telitel, F. Stoffelbach, B. Graff, F. Morlet-Savary, J. Lalevée, L. Fensterbank, J.-P. Goddard, C. Ollivier, Polym. Chem. 2015, 6, 4605-4611.

[104] J. Xu, K. Jung, A. Atme, S. Shanmugam, C. Boyer, J. Am. Chem. Soc. 2014, 136, 5508-5519.

[105] S. Shanmugam, C. Boyer, J. Am. Chem. Soc. 2015, 137, 9988-9999.

[106] a) C. Fu, J. Xu, L. Tao, C. Boyer, ACS Macro Lett. 2014, 3, 633-638; b) J. Xu, K. Jung, C. Boyer, Macromolecules 2014, 47, 4217-4229; c) J. W. Kramer, C. J. Hawker, B. P. Fors, N. J. Treat, Dow Global Technologies LLC, USA; University of California Santa Barbara . 2015, p. WO2015157149A2015157141.

[107] S. Shanmugam, J. Xu, C. Boyer, Macromolecules 2014, 47, 4930-4942.

[108] J. Xu, S. Shanmugam, H. T. Duong, C. Boyer, Polym. Chem. 2015, 6, 5615-5624.

[109] M. Chen, M. J. MacLeod, J. A. Johnson, ACS Macro Lett. 2015, 4, 566-569.

[110] S. Shanmugam, J. Xu, C. Boyer, J. Am. Chem. Soc. 2015, 137, 9174-9185.

[111] J. Xu, S. Shanmugam, C. Boyer, ACS Macro Lett. 2015, 4, 926-932.

[112] S. Shanmugam, J. Xu, C. Boyer, Chem. Sci. 2015, 6, 1341-1349.

[113] S. Shanmugam, J. Xu, C. Boyer, Angew. Chem., Int. Ed. 2016, 55, 1036-1040.

[114] J. Xu, K. Jung, N. A. Corrigan, C. Boyer, Chem. Sci. 2014, 5, 3568-3575.

[115] K. Jung, J. Xu, P. B. Zetterlund, C. Boyer, ACS Macro Lett. 2015, 4, 1139-1143.

[116] J. Yeow, J. Xu, C. Boyer, ACS Macro Lett. 2015, 4, 984-990.

[117] J. Xu, S. Shanmugam, N. A. Corrigan, C. Boyer, ACS Symp. Ser. 2015, 1187, $247-$ 267. 
[118] a) B. P. Fors, C. J. Hawker, Angew. Chem., Int. Ed. 2012, 51, 8850-8853; b) N. J. Treat, B. P. Fors, J. W. Kramer, M. Christianson, C.-Y. Chiu, J. Read de Alaniz, C. J. Hawker, ACS Macro Lett. 2014, 3, 580-584.

[119] S. Telitel, F. Dumur, S. Telitel, O. Soppera, M. Lepeltier, Y. Guillaneuf, J. Poly, F. Morlet-Savary, P. Fioux, J.-P. Fouassier, D. Gigmes, J. Lalevée, Polym. Chem. 2015, 6, 613-624.

[120] J. E. Poelma, B. P. Fors, G. F. Meyers, J. W. Kramer, C. J. Hawker, Angew. Chem., Int. Ed. 2013, 52, 6844-6848.

[121] X. Zhang, C. Zhao, Y. Ma, H. Chen, W. Yang, Macromol. Chem. Phys. 2013, 214, 2624-2631.

[122] Q. Liu, L. Liu, Y. Ma, C. Zhao, W. Yang, J. Polym. Sci., Part A: Polym. Chem. 2014, 52, 3283-3291.

[123] E. Hrsic, H. Keul, M. Möller, Macromol. Rapid Commun. 2015, 36, 2092-2096.

[124] S. Mommer, J. Köhler, H. Keul, M. Möller, Macromol. Chem. Phys. 2016, 217, 9-23.

[125] A. Melker, B. P. Fors, C. J. Hawker, J. E. Poelma, J. Polym. Sci., Part A: Polym. Chem. 2015, 53, 2693-2698.

[126] N. J. Treat, H. Sprafke, J. W. Kramer, P. G. Clark, B. E. Barton, J. Read de Alaniz, B. P. Fors, C. J. Hawker, J. Am. Chem. Soc. 2014, 136, 16096-16101.

[127] E. H. Discekici, N. J. Treat, S. O. Poelma, K. M. Mattson, Z. M. Hudson, Y. Luo, C. J. Hawker, J. R. de Alaniz, Chem. Commun. 2015, 51, 11705-11708.

[128] X. Pan, M. Lamson, J. Yan, K. Matyjaszewski, ACS Macro Lett. 2015, 4, 192-196.

[129] G. M. Miyake, J. C. Theriot, Macromolecules 2014, 47, 8255-8261.

[130] A. Goto, T. Suzuki, H. Ohfuji, M. Tanishima, T. Fukuda, Y. Tsujii, H. Kaji, Macromolecules 2011, 44, 8709-8715.

[131] a) A. Ohtsuki, A. Goto, H. Kaji, Macromolecules 2013, 46, 96-102; b) A. Ohtsuki, L. Lei, M. Tanishima, A. Goto, H. Kaji, J. Am. Chem. Soc. 2015, 137, 5610-5617; c) A. Goto, J. Photopolym. Sci. Technol. 2015, 28, 37-42.

[132] Q. Fu, T. G. McKenzie, S. Tan, E. Nam, G. G. Qiao, Polym. Chem. 2015, 6, 53625368 .

[133] a) C. H. Bamford, R. Denyer, Nature 1968, 217, 59-60; b) M. Ciftci, P. Batat, A. L. Demirel, G. Xu, M. Buchmeiser, Y. Yagci, Macromolecules 2013, 46, 6395-6401.

[134] M. Ciftci, S. Norsic, C. Boisson, F. D'Agosto, Y. Yagci, Macromol. Chem. Phys. 2015, 216, 958-963.

[135] a) C. P. Simpson, O. I. Adebolu, J.-S. Kim, V. Vasu, A. D. Asandei, Macromolecules 2015, 48, 6404-6420; b) P. Černoch, S. Petrova, Z. Černochová, J.-S. Kim, C. P. Simpson, A. D. Asandei, Eur. Polym. J. 2015, 68, 460-470; c) A. Vitale, R. Bongiovanni, B. Ameduri, Chem. Rev. 2015, 115, 8835-8866; d) A. D. Asandei, O. I. Adebolu, C. P. Simpson, J. Am. Chem. Soc. 2012, 134, 6080-6083.

[136] K. Koumura, K. Satoh, M. Kamigaito, Macromolecules 2008, 41, 7359-7367. 
TOC graphic:

Photo-initiated Polymerization

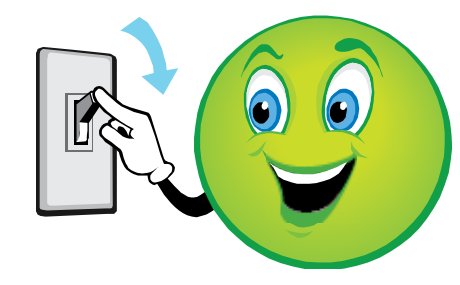

